\title{
Hermeneutic in Indonesian Classic Literature
}

\author{
Y S Hartati ${ }^{1}$, E Setia $^{2}$, Samsiarni $^{3}$, A Laila $^{4}$, W Rahmat ${ }^{5}$ \\ $1,2,3,4,5$ STKIP PGRI Sumatera Barat \\ \{yuliasri@stkip-pgri-sumbar.ac.id ${ }^{1}$, emil@stkip-pgri-sumbar.ac.id², Samsiarni@stkip-pgri- \\ sumbar.ac.id ${ }^{3}$, aruna@stkip-pgri-sumbar.ac.id4,wahyudi@stkip-pgri-sumbar.ac.id $\left.{ }^{5}\right\}$
}

\begin{abstract}
The issue of religion is one of the ideas of the creation of works that are always rife to be discussed, especially in literary works. Literary work is a document that records the past reality according to the author's observation, scrutiny and subjective thinking. Short story "Collapse of our Surau" is a symbol of the Minang people who have a philosophy. This type of research is qualitative with the content analysis method with a hermeneutic approach. The data source of this research is the short story "Collapse of Our Surau" by A.A. Navis. Based on the results of the discussion, it was concluded that this short story hermeneutically has the implicit meaning of the text. In this short story that collapsed is not surau. Surau is only a symbol used by A.A. Navis as a substitute for the fading of human understanding of the essence of life. As a symbol, this short story describes the attitudes and behavior of human beings who do charity without knowledge.
\end{abstract}

Keywords: Study, Hermeneutics, Short Stories

\section{INTRODUCTION}

Literature is not just a work of fiction that juggles facts into fiction, but also notes a testimony or a series of events that occur at certain times and times. The record sometimes results from an interpretation and evaluation of one or various events that occur in life. Therefore, there are not a few literary works that hint at signs, clues, predictions or just portraits in the future. Literature is a kind of historical record, a historical fact of author subjectivity. In addition, literature also records and records social situations at certain times and then tries to interpret them for life, so hermeneutic science is an interpretation of the general problems in understanding texts including literary texts. [1] The interpreter not only possesses the art of exegesis [Auslegung]; he or she also knows how to justify the exegesis theoretically.

The world in literature is a mimesis of events that occur in everyday life (imitation of reality). Therefore, literature is a document that records the past reality according to the author's observation, scrutiny and subjective thinking. Likewise, the short story which is one of the literary prose genre serves as the shape of the character of the reader. Similar things [2], namely "This is in accordance with the purpose in the creation of short stories or other literary works which in the end is to foster the personality of society, especially teenagers from all things that can damage and influence their image as heirs of the nation". Thus, the reality is present for the sake of thought itself. 
The issue of religion is one of the ideas of creating works that are always warm to talk about. One of them is the short story "Breaking Our Surau" by A.A. Navis will be analyzed from a hermeneutic point of view. Hermeneutics is an important element in understanding or giving meaning from a text. Short Story "Robohnya Suarau Kami" by A.A. Navis is a symbol of the Minang people who have the philosophy of "adat basandi sarak, sarak basandi Kitabullah". This short story is a symbol of the Minangkabau community far ahead when this short story was made. The philosophy that rooted religion as the foundation of life began to fade in this short story. Imbalance has occurred in humans in interpreting life. Surau which collapsed is not a literal meaning that signifies the loss of a place of worship. But it is a symbol of the collapse of human morals which only understands one concept of divinity.

Thus, the collapse of the Surau We are a symbol of a culture in this case is the culture of the Minang community. Hermeneutics is a theory of the workings of understanding in interpreting texts that interpret them through a symbol. In line with [3] The hermeneutical reading of the text means dialogue with the text itself. According to Gadamer, to obtain the meaning closest to a text is to dialogue with the author's fusion horizon, text horizon and interpreter's horizon. In this case, the formulation of the problem of this research is "How do short stories "Robohnya Surau Kami " by A.A. Navis with a hermeneutic approach?"

Etymologically, the word hermeneutics comes from Greek, hermeneuein, which means to interpret. In Greek mythology, this word is often associated with a character named Hermes, a messenger who has the task of conveying Jupiter's message to humans. The task of conveying a message also means transferring the words of the gods into a language that can be understood by humans.

According to Paul Ricouer (in Rafiek, 2010: 3-4) hermeneutics is a theory of the workings of understanding in interpreting texts. In other words, hermeneutics is a decomposition process that moves from content and meaning that looks toward hidden and hidden meanings. The object of interpretation is that it can be a symbol in a dream or even myths of symbols in society or literature. In his study, Recouer distinguishes between univocal and equivocal symbols. Univocal symbols are signs with one meaning that is marked, such as symbols in logic. While equivocal symbols are the true symbols of hermeneutics.

Recouer studies (in WM., 2008: 16) distinguish between univocal and equivocal symbols. Univocal symbols are signs with one signified meaning, such as symbols in logic. While the equivocal symbol is the real focus of hermeneutics, relating to symbolic text has a multimantic meaning and can form a semantic unity which has (as in myth) a surface meaning that is truly coherent and at the same time contains deeper significance.

Palmer (in WM., 2008: 24) summarizes six hermeneutic definitions, namely first, hermeneutics as the theory of Biblical Exegesis (interpretation). Second, hermeneutics as a philological methodology, third, hermeneutics as a science of linguistic understanding, fourth, hermeneutics as the basis of social-humanities methodology, fifth, hermeneutics as Dasein's phenomenology and existential understanding. Sixth, hermeneutics as a system of interpretation; find meaning vs. iconoclasm. Meanwhile Mircea Eliade defines hermeneutics as the art of interpretation, in which there are three important components that cannot be separated, namely the text, interpreter, and reader.

Ricouer (in Rafiek, 2010: 7) describes the hermeneutical work procedure as follows: the first step, is the symbolic step from symbol to symbol. The second step is giving meaning by symbols and careful excavation of meaning. The third step, is a truly philosophical step, namely to use symbols as a starting point. These three steps have a close relationship with the steps of understanding language, namely semanti (level of pure language), reflexive (higher 
level of knowledge, which approaches the level of ontology), and existential or ontologism (understanding the level of being or the existence of meaning).

Hermeneutics is closely related to structural analysis. Structural analysis is a logical means to decipher the text (the object being interpreted). [4] Then hermeneutic analysis moves further from the study of structure, hermeneutic analysis involves a variety of relevant disciplines that allow interpretation to be broader and deeper. However, various structural elements that are symbolic cannot be dismantled by only the relations between these elements. Therefore, hermeneutic interpretation includes knowledge which is possible to participate in forming it; psychology, sociology, politics, anthropology, history, etc. This is what is meant by the distortion of the world of text (object) and self-understanding. In other words, if the text is understood through an analysis of the relations between the elements (structural), other fields that have not been touched can be understood through the fields of science and other methods that are relevant and possible. The same thing was said by. The hermeneutic method which includes verstehen, erklaren, and reflection tries to put literature in its place as art which is a tool to perfect human existence.

According to Ricoeur (in Rafiek, 2010: 10), there is no structural analysis without a hermeneutic understanding of the inheritance of meaning without metaphor, without translation, without giving indirect meaning that creates semantic fields, namely the basis of observable structural homologies.

\section{RESEARCH METHOD}

This type of research is qualitative research which focuses on content analysis. According to Semi (1993: 23) "Qualitative research is research carried out by not using numbers, but using depth of appreciation of the interaction between concepts that are empirical. [5] Content analysts' best guarantee against the contamination of texts by the takes their sources have in how their texts are analyzed is to focus on textual karues of which their sources are unconscious, or to apply categories the sources of their texts are unable to control. Then Hasanuddin WS. (1998: 3) "Content analysis is analyzing the contents of literature as a product of communication from an author to the reader". Manuscripts that are sampled are described and explained based on the relationship between the information contained in them. The process of deciphering and explaining is continued with interpretation.

\section{RESULTS AND DISCUSSION}

The story in the short story Robohnya Surau Kami by A.A. Navis portrays humans who attach importance to relationships with their creators, while relationships with humans are ignored. This is illustrated by the figure of the grandfather who became garin at a surau.

Sedari muda aku di sini, bukan? Tak kuingat punya isteri, punya anak, punya keluarga seperti orang lain, tahu? [...] Alhamdulillah kataku bila aku menerima karunia-Nya. Astagfirullah kataku bila aku terkejut. Masya Allah kataku bila aku kagum. Apa salahnya pekerjaanku itu? Tapi kini aku dikatakan manusia terkutuk (Navis, 2010:5).

Based on the above quote can be explained the side of human life. The grandfather figure in the quote is not willing to be said to be a damned man. This is narrated through a text which states that grandfather's life had been intended only for God. He always worshiped obediently, 
always echoed the call to prayer, and read the scriptures. Because that form of love for God is what makes grandfather neglect worldly life that should not be forgotten.

Grandfather has no desire for his worldly life. Naturally, humans must have the desire to have a wife, have children, and an established life in financial terms. Grandfather is a symbol of man who has complete obedience to God. However, fear of damage to obedience was due to worldly factors that made the grandfather choose not to settle down.

..."Pisau siapa, Kek?"

"Ajo Sidi."

"Ajo Sidi?"

Kakek tak menyahut. Maka aku ingat Ajo Sidi, si pembual itu. Sudah lama aku tak ketemu dia. Dan aku ingin ketemu dia lagi. Aku senang mendengar bualannya. Ajo Sidi bisa mengikat orang-orang dengan bualannya yang anehaneh sepanjang hari. [...] Tiba-tiba aku ingat lagi pada Kakek dan kedatangan Ajo Sidi kepadanya. Apakah Ajo Sidi telah membuat bualan tentang Kakek? Dan bualan itukah yang mendurjakan Kakek? Aku ingin tahu. Lalu aku tanya Kakek lagi. "Apa ceritanya, Kek?” (Navis, 2010:3)

Ajo Sidi, this is a call that is very familiar to the Minang people. Ajo Sidi is a call for the people of Pariaman. As a cultural symbol, certainly A.A. Navis has the intention of choosing a name that represents the culture of one of the Minang communities. Pariaman people are known to be good at speaking (symbolized by the character Ajo Sidi who boasted a story to grandfather). Bragging proficiency represents the character of some Minang people known as the gadang ota. Boasting is a contentless conversation that is sometimes sought to be conveyed to others. Sometimes the boasting teases people around and harms others.

"Pada suatu waktu, 'kata Ajo Sidi memulai, 'di akhirat Tuhan Allah memeriksa orang-orang yang sudah berpulang. Para malaikat bertugas di samping-Nya [...] Dan ketika ia melihat orang yang masuk ke surga, ia melambaikan tangannya, seolah hendak mengatakan 'selamat ketemu nanti'....

(Navis, 2010:6)

Humans are basically servants who are always tawadhu. However, that nature changed because of the negligence that made them become arrogant. Feeling the best and most true self that is done by Haji Saleh is a human symbol that only justifies the logic that makes him sure he can enter heaven. This is what many people do, do something without returning it to the true teachings in accordance with the rules of religion.

... Lalu Tuhan mengajukan pertanyaan pertama.

'Engkau?'

'Aku Saleh. Tapi karena aku sudah ke Mekah, Haji Saleh namaku.' ‘...

'apa kerjamu di dunia?'

'Aku menyembah Engkau selalu, Tuhanku.'

'Lain?'

'Setiap hari, setiap malam. Bahkan setiap masa aku menyebut-nyebut namaMu.'

'Lain.'

$[\ldots]$

Tidak. Kamu semua mesti masuk neraka. hai, Malaikat, halaulah mereka ini kembali ke neraka. Letakkan di keraknya!" 
The dialogue between Haji Saleh and God depicts humans who are only concerned with personal interests. Haji Saleh's protest against God's decision to put him in hell was a form of human dissatisfaction. The protest did not have a strong foundation. The thing that is relied on to appeal is the worship they do. When God made them aware of the arguments that were in accordance with religious teachings, then Haji Saleh realized his mistake.

In Islamic teachings, two main elements must be fulfilled by a servant. Relations with creators (habluminallah) and relations with fellow humans (habluminannas). Thinking only by multiplying worship to God and then being able to reach God's heaven is something wrong. In the teachings of Islam, humans must balance between worship to God and social relations with humans. Habluminallah is a human relationship with God. This relationship basically covers habluminannas and habluminal'alam.

Every worship ordered by God is to increase vertical and horizontal relations equally. Vertical relationship is our relationship to Allah (Habluminallah), while horizontal relations are our relationship to fellow creatures of Allah (Habluminannas). Therefore, practicing religion must be with science so that what we do is right.

Tapi kakek ini sudah tidak ada lagi sekarang. Ia sudah meninggal. Dan tinggallah surau itu tanpa penjaganya. Hingga anak-anak menggunakannya sebagai tempat bermain, memainkan segala apa yang disukai mereka. Perempuan yang kehabisan kayu bakar, sering suka mencopoti papan dinding atau lantai di malam hari. Jika Tuan datang sekarang, hanya akan menjumpai gambaran yang mengesankan suatu kesucian yang bakal roboh. Dan kerobohan itu kian hari kian cepat berlangsungnya. Secepat anak-anak berlari di dalamnya, secepat perempuan mencopoti pekayuannya. Dan yang terutama ialah sifat masa bodoh manusia sekarang, yang tak hendak memelihara apa yang tidak di jaga lagi (Navis, 2010:2).

The above quote is a symbol of the community that A.A. wants to convey. navis to the reader. Surau without guards, whose wood is sometimes taken as a substitute for firewood for women. Based on the work of [1] hermeneutics In contrast to this, when we use the term 'hermeneutics' today we stand in the scientific tradition of the modern era, 'Robohnya Surau Kami is a symbol of the collapse of human faith and the meaning of the fading of the Minangkabau indigenous culture affected by foreign culture. This is also relevant to the results of the study [3] stating that, Gadamer's hermeneutical theory was applied to the Ikhtilas novel by Hani Naqshabandi, the reader became aware that a cultural revolution movement was taking place in Saudi Arabia. This movement, among others, was marked by the emergence of awareness of people's freedom of understanding religion and tradition. Religious practice is demanded as something in accordance with justice and rationality [13]. This began with the awareness of the need for redefinition of humans themselves, especially women. However, the difference in this research with research [3] is based on the short story hermeneutic theory The collapse of Suarau We invite readers, especially men, to always protect and protect their people, especially women to avoid immoral acts and acts that violate the customary rules applies in Minangkabau. This is based on the hermeneutic definition proposed by Palmer (in WM., 2008: 24), that hermeneutics is the basis of social-humanities methodology which is reflected in the relationship between men and women based on traditional rules in Minangkabau. 


\section{CONCLUSIONS}

"Robohnya Surau Kami" is a symbol of social, cultural and religious. As a symbol, this short story describes the attitudes and behavior of human beings who do charity without knowledge. Understanding something is not accurate. If humans understand the true essence of life, they will understand that there must be a balance between creator and human.

Hermeneutic studies examine this short story in the process of interpretation. Dismantle the implicit meaning of the text. In this short story that collapsed is not surau. Surau is only a symbol used by A.A. Navis as a substitute for the fading of human understanding of the essence of life. Surau which represents the divine life with prayer in it, and represents the social essence of society by gathering there. Because the Minangkabau community used to be, Surau is not only a place of worship but also a place for deliberation.

\section{ACKNOWLEDGMENTS}

Praise the presence of Allah swt. for His mercy and guidance, the writing team succeeded in making this scientific article based on the results of joint research. As well as the author's team would like to thank: the ranks of the leadership of the STKIP PGRI Sumatera Barat, the leaders of the Language and Literature Education Study Program, and those who were not mentioned who had helped and motivated this research. May all good deeds be accepted and rewarded. Amen.

\section{REFERENCES}

[1] H. Gadamer, "Classical and Philosophical Hermeneutics", (SAGE, London, Thousand Oaks New Delhi), vol 23, no 1, bll 29-56, 2006.

[2] E. Septia, "EROTIS DAN GAYA PENCERITAAN DALAM KUMPULAN CERPEN KARYA DJENAR MAESA AYU”, Gramatika, vol 2, bll 101-117, 2016.

[3] M. Yusuf, "Sastra dan Transformasi Budaya (Analisis Hermeneutika Gadamer terhadap Novel Ikhtilas Karya hani Naqshabandi)", repository.uinjkt, 2017.

[4] Rohim, "Cerita humor pak andir", Atavisme, vol 17, bll 85-93, 2014.

[5] K. H. Krippendorff, Content Analysis: An Introduction to Its Methodology. London: Sage Publications, 2004.

[6] Handryant, Aisyah N. 2010. Masjid Sebagai Pusat Pengembangan Masyarakat: Intregasi Konsep habluminallah, habluminannas, dan habluminal'alam. UIN: Malang Press.

[7] Navis, A.A. 2010. Robohnya Surau Kami. Jakarta: PT Gramedia Pustaka Utama.

[8] Rafiek, 2010. Teori Sastra, Kajian Teori dan Praktik. Bandung: PT Refika Utama.

[9] Tharsyah, Adnan. 2004. Manusia-Manusia yang Dicintai Allah. Bandung: PT Mizan Pustaka.

[10] WM, Abdul Hadi . 2008. Hermeneutika Sastra Barat dan Timur. Jakarta: Pusat Bahasa.

[11] W. Poespoprodjo. 2004. Hermeneutika. Bandung: CV Pustaka Setia.

[12] Mahayana, Maman S. "Fakta dan Fiksi: Pertalian Sastra dan Sejarah." http://www.sastraindonesia.com/2009/01/ (diakses 28 Desember 2014).

[13] K. Saddhono, "Integrating Culture in Indonesian Language Learning for Foreign Speakers at Indonesian Universities." J. of Lang. and Lit. vol. 6 no.2 pp. 349-353, 2015 